\title{
Economic Analysis of Climate-Smart Agriculture Technologies in Maize Production in Smallholder Farming Systems
}

\author{
Angeline Mujeyi and Maxwell Mudhara
}

\section{Contents}

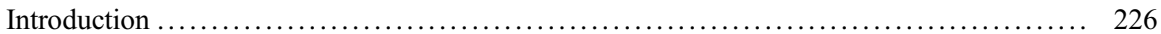

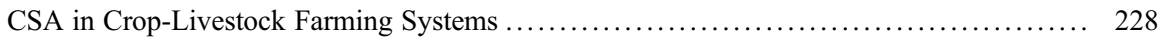

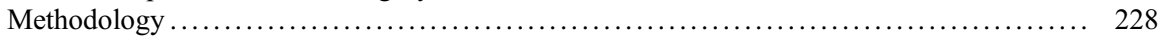

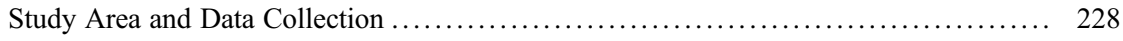

Data Analysis ......................................................... 229

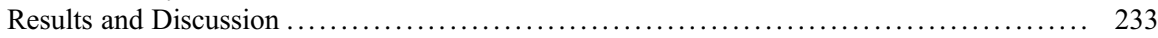

CSA Adaptation Strategies Employed by Households in Maize Production ........... 233

Economic Analysis of Maize ............................................. 235

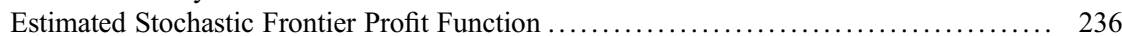

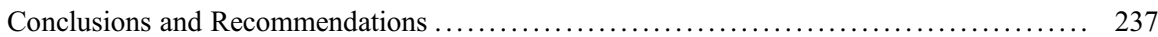

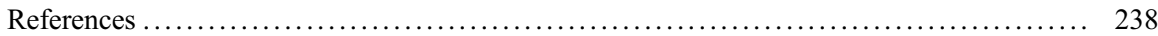

\section{Abstract}

Smallholder farmers who grow the staple maize crop rely mainly on rain-fed agricultural production, and yields are estimated to have decreased by over $50 \%$ largely due to climate change. Climate-smart agriculture (CSA) technologies, as adaptive strategies, are thus increasingly being promoted to overcome problems of declining agricultural productivity and reduced technical efficiency. This study analyzed profitability and profit efficiency in maize (Zea mays) production as a result of CSA technology adoption using cost-benefit analysis and stochastic profit frontier model. The study used data from a

\footnotetext{
This chapter was previously published non-open access with exclusive rights reserved by the Publisher. It has been changed retrospectively to open access under a CC BY 4.0 license and the copyright holder is "The Author(s)". For further details, please see the license information at the end of the chapter.
}

\footnotetext{
A. Mujeyi $(\bowtie) \cdot$ M. Mudhara

College of Agricultural, Engineering and Science, Discipline of Agricultural Economics, University of KwaZulu-Natal, Scottsville, Pietermaritzburg, South Africa

e-mail: Mudhara@ukzn.ac.za
} 
cross-sectional household survey of 386 households drawn from 4 districts in Mashonaland East province located in the northeastern part of Zimbabwe. Results from the cost-benefit analysis reveal that maize performs best under CSA technologies. The profit inefficiency model shows that extension contact, number of local traders, and adoption of CSA had significant negative coefficients indicating that as these variables increase, profit efficiency among maize-growing farmers increases. This implies that profit inefficiency in maize production can be reduced significantly with improvement in extension contact, access to farm gate/local markets, and adoption of CSA. The findings call for development practitioners to incorporate market linkages that bring buyers closer to the farmers, support for extension to be able to have frequent contacts with farmers, and promotion of CSA adoption.

\section{Keywords}

Cost-benefit analysis $\cdot$ Return on investment $\cdot$ Profit efficiency $\cdot$ Stochastic frontier $\cdot$ Zimbabwe

\section{Introduction}

Maize (Zea mays L.) is the most important cereal crop in sub-Saharan Africa and is the world's most widely grown cereal crop as well as essential food source for millions of the world's poor (Abate et al. 2017). In sub-Saharan Africa, maize is a staple food for an estimated $50 \%$ of the population and an important source of carbohydrate, protein, iron, vitamins (A, B, E, and K), and minerals (magnesium, potassium, and phosphorus) and is grown on an estimated 100 million hectares throughout the developing world (Nsikak-Abasi and Okon 2013; Siyuan et al. 2018). In 2018, Zimbabwe got approximately 730,437 tonnes of maize, and the average yield was $613.1 \mathrm{Kg}$ per hectare pointing to some technical inefficiencies. The average yield is lower as compared to the world average of $5923.7 \mathrm{Kg}$ tonnes/ ha and $2040.2 \mathrm{Kg} /$ ha for Africa in the same year (FAOSTAT 2020). The smallholder farmers rely mainly on rain-fed production and in addition are often constrained by multiple constraints such as reduced soil fertility; limited income to access inputs such as fertilizers, improved seed, herbicides, and pesticides; unavailability of lucrative output markets; high cost of inputs; and reduced yield due to climate variability (Poole 2017; Rurinda et al. 2014). Researchers and development practitioners have reported reductions in agricultural yield due to extreme weather (UNCCS 2019). These unpredictable seasons have become a major constraint in smallholder crop and livestock production farming systems, and as such, the use of climate-smart agriculture (CSA) technologies becomes essential as a solution. Climate-smart agriculture technologies are innovations that sustainably increase agricultural productivity, help households to adapt and be resilient to climate change, and contribute to the reduction of greenhouse gas emissions (Steward et al. 2018). 
Adaptation strategies for households can either be reactive (Shongwe et al. 2014), i.e., soil fertility maintenance through the use of animal manure and inorganic fertilizers, rotations, and intercropping in order to address problems linked to observed climate change impacts, or proactive CSA technologies such as use of new drought-tolerant varieties, use of early maturing varieties, and policy measures such as insurance policy. Zimbabwe has participated in interventions and alliances promoting CSA such as the DFID-funded Vuna (2015-2018) and the Africa Development Bank's Africa Climate-Smart Agriculture (ACSA) (2018-2025) (Thierfelder et al. 2017; Rosenstock et al. 2019). The Government of Zimbabwe (GoZ) has developed policies and interventions to lessen the impacts of climate change on agriculture. These policies include a child-friendly climate policy which targets education in schools on climate change issues, the climate-smart agriculture policy which promotes adoption of CSA by farmers, and the national climate policy which is targeting putting legal structures to guide businesses on becoming greener (GOZ 2018). Government and nongovernmental organizations have introduced a range of CSA in Zimbabwe which include conservation agriculture, drought-tolerant maize and legume varieties, cereal-legume intercropping and rotation systems, and improved fodder crops among others (Mujeyi 2018). Assuming economic rationality, smallholder farmers who rely on agriculture for livelihoods would adopt technologies that reduce costs of production while increasing benefits from greater incomes through improved yields. Smallholder farmers are heterogeneous, and as such, they adopt different combinations of CSA to address varying constraints that they face. These different technology bundles have different profitability levels because of the different input requirements associated with them as well as their potential impact on productivity.

The need to upscale CSA as adaptation mechanisms in order to improve or maintain high productivity levels in smallholder farming communities can effectively be achieved if profitability of these technologies and factors that enhance efficiency are properly understood. This study therefore aims to:

1. Estimate profitability and compare benefit-cost ratio (BCR) of maize production in smallholder farming communities across CSA technology bundles

2. Investigate the determinants of profit efficiency and identify the determinants thereof

The aim of this study is to contribute to the literature on CSA in Zimbabwe by analyzing profitability of current CSA technology bundles in maize production and technical inefficiency. Furthermore, using stochastic frontier model, the chapter aims to identify determinants of efficiency. The results will provide a better understanding of costs and benefits that would make it possible to design more economically efficient policies and programs to promote CSA technology adoption. Economic evaluations can provide critical information to those making decisions about the allocation of limited agriculture input resources across enterprises. The chapter provides empirical evidence from actual farmer behavior in uncontrolled environment, thus adding to studies from on-farm and on-station trials. 


\section{CSA in Crop-Livestock Farming Systems}

This study particularly chose to do analysis for maize (Zea mays) as it is the most important crop in smallholder farming systems in the four districts. Maize is the staple crop in Zimbabwe to $98 \%$ of the 12.7 million people in the country, and it provides $40-50 \%$ of the calories (Kassie et al. 2017). Average maize yield has dropped from a highest (after independence) of $2163.7 \mathrm{Kg} / \mathrm{ha}$ in 1985 to 667.8 $\mathrm{Kg} / \mathrm{ha}$ in 2017 (FAOSTAT 2020). Maize productivity has been negatively affected by infertile soils, inadequate water due to drought, and erratic rainfall patterns caused by climate change as well as incidence of pests and diseases. Various CSA technologies have been used in maize production in an effort to boost yields. One such technology is conservation agriculture (CA) which consists of three key principles, namely, minimum tillage, permanent soil cover (mulching with crop residues or cover crop), and crop diversification (either temporal diversification, $i$. e., rotation, or spatial diversification, i.e., intercropping). CA offers benefits of increased yields when properly followed. Crop rotation and intercropping improve soil fertility through the nitrogen fixing characteristics of legumes. Large increases in maize yields in maize-groundnut rotations have been reported by CIMMYT researchers in Zimbabwe from long-term trials in smallholder farming systems (Waddington et al. 2007). Cereal-legume rotations also have benefits of reducing build-up of pests and diseases. Minimum soil disturbance reduces the rate and amount of soil erosion. Soil cover leads to reduced runoff, reduced soil erosion, increased water infiltration, and reduced evaporation of soil moisture (Michler et al. 2019; Steward et al. 2018; Thierfelder et al. 2017). Drought-tolerant maize (DTM) varieties have been promoted by organizations such as CIMMYT, and these are input-responsive, stress-tolerant, and highyielding in comparison to traditionally grown commercial hybrids (Mujeyi and Mujeyi 2018).

\section{Methodology}

\section{Study Area and Data Collection}

This study uses data collected from a cross-sectional household survey using a structured interview in communities that were exposed to CSA technologies and data from key informant interviews with stakeholders who were involved in technology dissemination. Multistage sampling method was used to select the 386 respondents from maize-growing communities in 8 wards located in 4 districts, i.e., Goromonzi, Murehwa, Uzumba Maramba Pfungwe, and Mutoko. The economies of the four districts are integrated crop-livestock farming systems that rely on rain-fed production. Maize is the main cereal staple crop, while groundnut is the leading legume crop. The main livestock kept by the farmers are cattle and goats. 
Livestock rely mainly on pastures for feed. Integration of the crop and livestock enterprises helps farmers to maximize resource uses. Stover from the field crops are used to feed livestock, while dung from the livestock is used to improve soil fertility through its use as manure.

Murehwa district falls under agro-ecological region IIB which is characterized by moderately high rainfall $(700 \mathrm{~mm}$ annually) and moderate temperatures for crop production. This district has predominantly sandy loamy soils. The majority of Motoko's communal area is in natural region IV which is characterized by subtropical climate with cool dry winter and hot rainy summers (650 to $700 \mathrm{~mm}$ rainfall annually). The soils are shallow to moderately deep, yellowish red, coarse-grained loamy sands. Goromonzi is located in natural region II which also gets moderately high rainfall. Uzumba Maramba Pfungwe (UMP) has two natural regions (natural regions II to $\mathrm{V}$ ), but wards were selected from natural region $\mathrm{V}$.

Two wards that have been exposed to CSA technologies were chosen from each district. Households were randomly selected from one randomly selected village in each ward. Sample households were distributed within the wards according to the ward sizes (proportionate sampling). The farm households were interviewed by trained enumerators during the 2017/2018 crop season.

\section{Data Analysis}

The study employed descriptive statistics and inferential statistics. It explored the economic assessment of CSA technologies through a cost-benefit analysis (CBA) and a stochastic profit frontier model. This study precisely probed farmers to state which CSA technologies they had used for various crops in one season and the inputs that were used and grain harvested after such an investment. Information from this economic analysis is important for price setting of commodities by government watchdogs, researchers working to improve the technologies, farmers using them, and donors and governments who fund research and development work.

\section{Economic Analysis of CSA}

Farmers use different technologies as adaptation strategies, and their decisions on which technology to adopt under what area depend on the cost-effectiveness (Shongwe et al. 2014). Cost-benefit analysis thus plays an important role of farmers' decisions with regard to input costs, e.g., fertilizer, labor, seed, pesticide, etc., and was used in the economic analysis. Other researchers have used CBA in analyzing CSA technologies (Papendiek et al. 2016; Sain et al. 2017). Cost-benefit analysis (CBA) compares inputs and outputs for a technology in monetary terms (Shongwe et al. 2014). CBA for this study focuses on the quantitative evaluation of CSA technologies on the maize crop. All benefits and costs are estimated in monetary terms, and through calculating net benefits, the most economic efficient CSA are 
identified. Benefits from maize include grain and stover used to feed livestock. The net benefits are calculated as follows:

$$
\begin{aligned}
& \mathrm{NB}=\Sigma(\mathrm{Bt}-\mathrm{Ct}) \\
& \mathrm{NB}=\Sigma \mathrm{Bt}-\Sigma \mathrm{Ct}
\end{aligned}
$$

where:

NB represents the net benefits.

$\Sigma \mathrm{Bt}=$ total benefits in year $\mathrm{t}$.

$\Sigma \mathrm{Ct}=$ total variable costs (TVC) in year $\mathrm{t}$.

$\mathrm{Bt}$ is the combination of revenue from quantity of grain output and stover benefits.

$$
\begin{aligned}
\Sigma \mathrm{Bt}= & \text { Total Revenue } \\
= & \Sigma(\text { Grain Output }(\mathrm{Kg}) * \text { Unit grain prices }(\$ / \mathrm{Kg}) \\
& +(\text { Stover Output }(\mathrm{Kg}) * \text { Unit stover prices })
\end{aligned}
$$

Average local market prices obtained by the farmers were used to compute returns. The farm gate price of the output is the value (price) farmers receive or can receive for their harvested crops. Total variable input costs refer to the sum of all variable input costs and vary from one CSA technology to another.

$$
\begin{aligned}
\mathrm{TVC}= & \Sigma \mathrm{Ct} \\
= & \mathrm{P}_{\text {landprep }} \mathrm{Q}_{\text {landprepr }}+\mathrm{P}_{\text {basalfertiliser }} \mathrm{Q}_{\text {basalfertiliser }} \\
& +\mathrm{P}_{\text {topdressingfertiliser }} \mathrm{Q}_{\text {topdressingfertiliser }}+\mathrm{P}_{\text {seed }} \mathrm{Q}_{\text {seed }}+\mathrm{P}_{\text {labor }} \mathrm{Q}_{\text {labor }}+\ldots \\
& +\mathrm{P}_{\mathrm{n}} \mathrm{Q}_{\mathrm{n}}
\end{aligned}
$$

The benefit-to-cost ratio (BCR) which is a financial ratio that is used to determine whether the amount of money made through a project will be greater than the costs incurred in executing was also computed as follows:

$$
\mathrm{BCR}=(\text { Benefit } / \text { Costs })
$$

For each CSA technology, the total costs incurred when using that strategy and benefits were used to compute the net benefit for that particular adaptation strategy.

\section{Return on Investment}

Return on investment values help link the value of technologies to users. The return on investment (ROI) value is more powerful than the benefit-cost ratio because the ROI value shows the net return for a $\$ 100$ investment.

$$
\mathrm{ROI}=(\text { Net Benefit } / \mathrm{TVC}) * 100
$$




\section{The Stochastic Profit Frontier Model}

The stochastic frontier models have been used extensively even in agriculture, to model input-output relationships and to measure the technical efficiency (Greene 2010). These were first proposed in the context of production function estimation to account for the effect of technical inefficiency (Wang 2008; Dziwornu and Sarpong 2014). The analytical method has been used to compare the performance of farmers under different technological regimes. For example, the method has been used to examine the impact of technology adoption on output and technical efficiency of rice farmers or even beef farmers under various production systems (Omhile et al. 2016; Villano and Fleming 2006). In this study, the stochastic profit frontier model is used to compare inefficiency of farmers using CSA versus those who are not using any CSA technology. The model captures inefficiencies associated with different endowments as well as input and output prices. The model is specified as follows:

$$
\mathrm{y}=\beta^{\prime} \mathrm{x}+\varepsilon_{\mathrm{i}}
$$

where $\mathrm{y}$ is the observed outcome in this case maize profitability estimated by the gross margin (goal attainment), $\mathrm{x}$ is the logarithm of costs of that input, coefficient $\beta$ are parameters estimated, and $\varepsilon_{\mathrm{i}}$ is the error term. The error structure is specified as follows:

$$
\varepsilon_{\mathrm{i}}==\mathrm{v}_{\mathrm{j}}-\mathrm{u}_{\mathrm{j}}
$$

where $\mathrm{v}_{\mathrm{j}}$ is the random error term and $\mathrm{u}_{\mathrm{j}}$ is the inefficiency effects of farm $\mathrm{j}$.

$\mathrm{Uj}$ is independently distributed with mean $\mu_{1}$ and variance $\sigma^{2}$.

Thus, the stochastic model is:

$$
y=\beta^{\prime} x+v_{j}-u_{j},
$$

$\beta^{\prime} \mathrm{x}+\mathrm{v}$ is the optimal, frontier goal (e.g., maximal production output or minimum cost) pursued by the individual, $\beta^{\prime} \mathrm{x}$ is the deterministic part of the frontier, and $\mathrm{v} \sim \mathrm{N}$ $\left[0, \sigma \mathrm{V}^{2}\right]$ is the stochastic part. $v_{j}$ is the stochastic error term, and $u_{j}$ is a one-sided error representing the technical inefficiency of firm $j$. Both $v_{j}$ and $u_{j}$ are assumed to be independently and identically distributed.

Inefficiency model is modelled using farm-specific, market-specific, and household characteristics and can therefore be estimated as follows:

$$
\begin{gathered}
\mathrm{U}_{\mathrm{j}}=\alpha+\alpha_{\mathrm{i}} \mathrm{Z}_{\mathrm{i}}+\varepsilon \mathrm{i} \\
\mathrm{U}_{\mathrm{j}}=\alpha+\alpha_{1} \mathrm{Z}_{1+} \alpha_{2} \mathrm{Z} \alpha_{2+} \alpha_{3} \mathrm{Z}_{3}+\ldots \alpha_{\mathrm{n}} \mathrm{Z}_{\mathrm{n}}+\varepsilon_{\mathrm{i}}
\end{gathered}
$$

where $U_{j}$ is technical inefficiency of the $j$ th farm.

$Z_{1}$ to $Z_{n}$ are the determinants and $\varepsilon_{i}$ is the disturbance term and the coefficients $\propto$ are parameters estimated. Stochastic frontier models allow to analyze technical inefficiency in the framework of production functions. Production units such as 
households are assumed to produce according to a common technology and reach the frontier when they produce the maximum possible output for a given set of inputs. Inefficiencies can be due to structural problems or market imperfections and other factors which cause countries to produce below their maximum attainable output. The stochastic frontier model decomposes growth of the output variable into changes in input use, changes in technology, and changes in efficiency. All parameters in the stochastic frontier and the technical inefficiency effects model are simultaneously calculated by a single-stage maximum likelihood estimation procedure using sfcross command in Stata (Karakaplan 2017). Table 1 gives a summary of all the variables thus used in the stochastic frontier model.

Table 1 Stochastic frontier model variables

\begin{tabular}{|c|c|c|c|}
\hline \multicolumn{4}{|c|}{ Frontier regression model (efficiency factors) } \\
\hline$y i$ & $y i$ & $\begin{array}{l}\text { Dependent variable - maize gross } \\
\text { margin in US\$ }\end{array}$ & Continuous variable \\
\hline $\mathrm{X} 1$ & SEEDcosts & Seed costs in US\$ & Continuous variable \\
\hline $\mathrm{X} 2$ & DFERTcosts & Basal fertilizer costs in US\$ & Continuous variable \\
\hline $\mathrm{X} 3$ & ANFERTcosts & Top dressing fertilizer costs in US\$ & Continuous variable \\
\hline $\mathrm{X} 4$ & LANDPREPcosts & Land preparation costs in US\$ & Continuous variable \\
\hline $\mathrm{X} 5$ & MANUREcosts & Manure costs in US\$ & Continuous variable \\
\hline $\mathrm{X} 6$ & HERBcosts & Herbicide costs in US\$ & Continuous variable \\
\hline $\mathrm{X} 7$ & PESTcosts & Pesticide costs in US\$ & Continuous variable \\
\hline $\mathrm{X} 8$ & LABOURcosts & Labor costs in US\$ & Continuous variable \\
\hline X9 & PACKcosts & Packaging costs in US\$ & Continuous variable \\
\hline $\mathrm{X} 10$ & OTHERcosts & Other costs in US\$ & Continuous variable \\
\hline \multicolumn{4}{|c|}{ Inefficiency model } \\
\hline $\mathrm{Z1}$ & HHSEX & Gender of household head & $\begin{array}{l}\text { Dummy, i.e., } 1=\text { male } \\
0=\text { female }\end{array}$ \\
\hline $\mathrm{Z} 2$ & HHEXPER & Experience household head (years) & Continuous variable \\
\hline $\mathrm{Z3}$ & MEMBERSHIP & Membership to farmer groups & $\begin{array}{l}\text { Dummy, i.e., } 1=\text { yes } \\
0=\text { no }\end{array}$ \\
\hline $\mathrm{Z4}$ & CREDIT & Access to credit & $\begin{array}{l}\text { Dummy, i.e., } 1=\text { yes } \\
0=\text { no }\end{array}$ \\
\hline $\mathrm{Z5}$ & TRADERS & Number of traders locally & Continuous variable \\
\hline Z6 & TAR & Distance to tar $(\mathrm{km})$ & Continuous variable \\
\hline$Z 7$ & Kmextension & Distance to extension $(\mathrm{Km})$ & Continuous variable \\
\hline Z8 & TLU & Total livestock units & Continuous variable \\
\hline Z9 & AGROREGION & Agro-ecological region & $\begin{array}{l}\text { Dummy, i.e., } 1=\text { wetter } \\
\text { (II) } \\
0=\text { otherwise (drier III } \\
\text { and IV) }\end{array}$ \\
\hline $\mathrm{Z} 10$ & EXTNcontact & Frequency of extension contact & Continuous variable \\
\hline Z11 & CSAadoption & Use of CSA in maize production & $\begin{array}{l}\text { Dummy, i.e., } 1=\text { yes } \\
0=\text { otherwise }\end{array}$ \\
\hline
\end{tabular}


Table 2 Maize CSA technologies

\begin{tabular}{l|c|c|c|c|c|c}
\hline Maize technology & Goromonzi & Murehwa & Mutoko & U.M.P & Whole sample & Chi square \\
\hline Intercropping & $24.0 \%$ & $21.6 \%$ & $2.0 \%$ & $5.4 \%$ & $16.1 \%$ & $24.23 * * *$ \\
\hline Sole CN & $5.5 \%$ & $7.2 \%$ & $0.0 \%$ & $6.5 \%$ & $5.4 \%$ & 3.66 \\
\hline Rotation & $39.0 \%$ & $54.6 \%$ & $66.0 \%$ & $47.3 \%$ & $48.4 \%$ & $12.88 * *$ \\
\hline Minimum tillage & $39.0 \%$ & $35.1 \%$ & $48.0 \%$ & $24.7 \%$ & $35.8 \%$ & $8.89 * *$ \\
\hline DT maize & $13.7 \%$ & $11.3 \%$ & $36.0 \%$ & $12.9 \%$ & $15.8 \%$ & $17.85 * * *$ \\
\hline Manure use & $13.7 \%$ & $21.6 \%$ & $14.0 \%$ & $8.6 \%$ & $14.5 \%$ & $6.69 *$ \\
\hline Mulching & $4.1 \%$ & $5.2 \%$ & $10.0 \%$ & $0.0 \%$ & $4.1 \%$ & $8.59 * *$ \\
\hline
\end{tabular}

$* * *, * *$, and $*$ indicates significance level at $1 \%, 5 \%$ and $10 \%$

\section{Results and Discussion}

Profitability across CSA technology bundles was estimated using cost-benefit analysis, and the stochastic profit frontier model was estimated to see if CSA adoption has a significant effect on technical inefficiency. Tables 2, 3, and 4 show the results of the analysis with subsequent discussions.

\section{CSA Adaptation Strategies Employed by Households in Maize Production}

Maize production is negatively affected by climate change, and as such, adoption of CSA technologies is key to increasing yields. Table 2 shows the CSA technologies currently being used by the farmers.

The results show that farmers use various CSA technologies in maize production, with crop rotation being the highest in Mutoko followed by Murehwa $(66 \%$ and $54.6 \%$, respectively). Minimum tillage and DT maize are highest in Mutoko (48\% and $36 \%$, respectively). Few farmers (less than 10\%) are not using any CSA technologies in maize production. This highlights the importance of CSA in the smallholder farming communities. Adoption of CSA such as intercropping, rotation, minimum tillage, DT maize, manure use, and mulching was significantly different across the study districts. Overall, CSA technology use is still low with less than $50 \%$ of households adopting CSA across all the districts except for rotation which is adopted by more than $50 \%$ of households in Murehwa and Mutoko districts. Farmers highlighted during FGDs that manure use had become low as there was an outbreak of theileriosis which led to most households being left with no cattle, which are the major source of manure. Manure from small ruminants and poultry is prioritized for use in horticulture gardens. Farmers also cited that technologies such as minimum tillage promoted by NGOs particularly basin making with hoes were strenuous in as much as they could be done bit by bit in the dry season for farmers with fencing. This was not so for the majority with unfenced fields who therefore needed to do it at the onset of the season. This has led to farmers shunning basins in favor of even hiring in 
Table 3 Results of cost-benefit analysis

\begin{tabular}{|c|c|c|c|c|c|}
\hline \multirow[b]{2}{*}{ Cost-benefit indicators } & \multicolumn{5}{|c|}{ Maize technology cluster } \\
\hline & $\begin{array}{l}\text { Cluster } 1 \\
\mathrm{~N}=178\end{array}$ & $\begin{array}{l}\text { Cluster } 2 \\
\mathrm{n}=163\end{array}$ & $\begin{array}{l}\text { Cluster } 3 \\
\mathrm{n}=24\end{array}$ & $\begin{array}{l}\text { Cluster } 4 \\
\mathrm{n}=21\end{array}$ & $\begin{array}{l}\text { ALL } \\
\mathrm{n}=386\end{array}$ \\
\hline Grain $(\mathrm{Kg})$ & 1646.41 & 1815.61 & 1833.51 & 1266.87 & 1711.02 \\
\hline Grain revenue (\$) & 643.94 & 705.14 & 752.63 & 488.18 & 668.91 \\
\hline Stover $(\mathrm{Kg})$ & 823.21 & 907.80 & 916.75 & 633.43 & 855.51 \\
\hline Stover revenue $(\$)$ & 32.93 & 36.31 & 36.67 & 25.34 & 34.22 \\
\hline Total revenue & 676.87 & 741.45 & 789.30 & 513.52 & 703.13 \\
\hline Land preparation costs & 68.85 & 65.37 & 67.81 & 77.46 & 67.75 \\
\hline Seed $(\mathrm{Kg})$ & 25.72 & 25.20 & 26.60 & 29.76 & 25.78 \\
\hline Seed costs $(\$)$ & 67.60 & 71.71 & 69.56 & 68.73 & 69.59 \\
\hline Compound D fertilizer $(\mathrm{Kg})$ & 204.97 & 208.33 & 247.40 & 180.58 & 207.80 \\
\hline Compound D fertilizer costs & 137.76 & 138.44 & 151.12 & 134.94 & 138.76 \\
\hline Ammonium nitrate fertilizer $(\mathrm{Kg})$ & 184.39 & 187.66 & 192.53 & 178.17 & 185.99 \\
\hline $\begin{array}{l}\text { Ammonium nitrate fertilizer } \\
\text { costs }(\$)\end{array}$ & 137.43 & 137.46 & 137.08 & 141.96 & 137.68 \\
\hline Manure (carts) & 0.00 & 0.02 & 0.00 & 0.00 & 0.01 \\
\hline Manure costs $(\$)$ & 30.39 & 33.22 & 47.60 & 30.16 & 32.72 \\
\hline Herbicide costs $(\$)$ & 1.55 & 2.01 & 0.29 & 0.48 & 1.61 \\
\hline Pesticide costs $(\$)$ & 0.38 & 0.23 & 2.08 & 0.00 & 0.40 \\
\hline Labor costs $(\$)$ & 66.36 & 72.74 & 47.67 & 119.05 & 70.91 \\
\hline Maize packaging costs $(\$)$ & 5.02 & 6.68 & 5.05 & 4.33 & 5.71 \\
\hline Other costs $(\$)$ & 0.21 & 0.88 & 2.03 & 0.00 & 0.61 \\
\hline Total variable costs (TVC) & 515.56 & 528.75 & 530.30 & 577.11 & 525.74 \\
\hline Gross margin & 161.30 & 212.70 & 259.00 & \begin{tabular}{|l|}
-63.59 \\
\end{tabular} & 177.39 \\
\hline BCR & 1.42 & 1.50 & 1.69 & 0.90 & 1.44 \\
\hline ROI & 42.17 & 50.06 & 68.82 & -9.59 & 44.42 \\
\hline
\end{tabular}

$* * *, * *$, and $*$ indicates significance level at $1 \%, 5 \%$ and $10 \%$

animal-based tillage services. Minimum tillage could be achieved using animaldrawn rippers and direct seeders, but farmers highlighted that there has been an outbreak of January diseases which saw farmers losing cattle and draft power was the hardest hit. Mulching and intercropping under maize also recorded the least frequencies. Farmers highlighted that mulching was difficult to come by given that stover was used to feed livestock. The study further identified CSA technology combinations in maize production using principal component analysis-clustering. Four distinctive clusters were identified, i.e., Technology Cluster 1 (dominantly minimum tillage with lower use of rotation, DT maize, manure, and intercrop), Technology Cluster 2 (dominantly rotation use with lower use of intercrop and very low DT, manure, and minimum tillage), Technology Cluster 3 (higher use of mulch, manure, and DT maize, average use of minimum tillage and rotation, and less intercrop), and Technology Cluster 4 (conventional). 
Table 4 The stochastic frontier model results

\begin{tabular}{|c|c|c|c|c|}
\hline \multicolumn{2}{|l|}{ Variables } & Coef. & Std. Err & $\mathrm{P}$ value \\
\hline \multicolumn{5}{|c|}{ Frontier regression model (efficiency factors) } \\
\hline $\mathrm{X} 1$ & SEEDcosts & 102.41 & 151.51 & 0.50 \\
\hline $\mathrm{X} 2$ & DFERTcosts & $-166.68 * *$ & 67.53 & 0.01 \\
\hline $\mathrm{X} 3$ & ANFERTcosts & -40.02 & 67.85 & 0.56 \\
\hline $\mathrm{X} 4$ & LANDPREPcosts & 106.57 & 105.16 & 0.31 \\
\hline $\mathrm{X} 5$ & MANUREcosts & 11.6 & 27.17 & 0.67 \\
\hline X6 & HERBcosts & -93.47 & 74.80 & 0.21 \\
\hline $\mathrm{X} 7$ & PESTcosts & 15.98 & 121.90 & 0.90 \\
\hline $\mathrm{X} 8$ & LABOURcosts & -28.28 & 24.82 & 0.25 \\
\hline X9 & PACKcosts & $1362.15 * * *$ & 79.66 & 0.00 \\
\hline \multirow[t]{2}{*}{$\mathrm{X} 10$} & OTHERcosts & $-208.07 * *$ & 96.51 & 0.03 \\
\hline & _cons & -642.06 & 324.50 & 0.05 \\
\hline \multicolumn{5}{|c|}{ Inefficiency model } \\
\hline $\mathrm{Z1}$ & HHSEX & -51.86 & 72.02 & 0.47 \\
\hline $\mathrm{Z2}$ & HHEXPER & $152.62 * *$ & 69.20 & 0.03 \\
\hline $\mathrm{Z3}$ & MEMBERSHIP & 18.08 & 63.86 & 0.78 \\
\hline $\mathrm{Z4}$ & CREDIT & 117.29 & 76.06 & 0.12 \\
\hline $\mathrm{Z5}$ & TRADERS & $-145.16^{* *}$ & 60.61 & 0.02 \\
\hline Z6 & TAR & -74.88 & 85.25 & 0.38 \\
\hline $\mathrm{Z7}$ & Kmextension & 100.71 & 64.87 & 0.12 \\
\hline Z8 & TLU & $181.94^{* * *}$ & 59.94 & 0.00 \\
\hline Z9 & AGROREGION & -60.21 & 63.55 & 0.34 \\
\hline $\mathrm{Z10}$ & EXTNcontact & $-167.5^{* *}$ & 82.10 & 0.04 \\
\hline \multirow[t]{2}{*}{$\mathrm{Z11}$} & CSAadoption & $-297.64 * *$ & 125.80 & 0.02 \\
\hline & _cons & $436.91^{* *}$ & 201.05 & 0.03 \\
\hline \multicolumn{5}{|l|}{ Usigma } \\
\hline _cons & & 4.65 & 7.77 & 0.55 \\
\hline \multicolumn{5}{|l|}{ Vsigma } \\
\hline _cons & & $11.78 * * *$ & 0.09 & 0.00 \\
\hline sigma_u & & 10.22 & 39.70 & 0.80 \\
\hline sigma_v & & $361.46 * * *$ & 15.36 & 0.00 \\
\hline Lambda & & 0.03 & 42.72 & 1.00 \\
\hline
\end{tabular}

$* * *, * *$, and $*$ indicate statistical significance at $1 \%, 5 \%$, and $10 \%$, respectively

\section{Economic Analysis of Maize}

Economic analysis was performed to estimate the net return and benefit-cost ratio in various CSA technology bundles. A comparison of costs and returns from various CSA technology combinations in maize production is presented in Table 3.

The results show that the farmers who used CSA had higher gross margin ranging from $\$ 259$ (return on investment of $69 \%$ ) with a BCR of 1.69 under higher CSA use 
to $\$ 161.30$ (return on investment of $42 \%$ ) and a BCR of 1.42 under low CSA use compared to a negative gross margin under sole conventional practices $(-\$ 63.59)$ with a BCR of 0.9 but negative ROI of close to $10 \%$. This indicates that farmers get at least more than $\$ 40$ for every $\$ 1$ spent in maize production using CSA technologies. The difference in profitability is mainly maybe a result of yield differences of conventional system versus CSA. These findings are consistent with the findings of Sain et al. (2017) who found that the incorporation of the CSA practices increased maize yields by $20 \%$ or more in comparison to existing farm management systems and Ali and Erenstein (2017) who found that yields differed according to production system and technology used.

\section{Estimated Stochastic Frontier Profit Function}

The analysis was done using the sfcross Stata commands for the estimation of parametric stochastic frontier (SF) models using cross-sectional data (Bell and Bellotti 2014; Newton et al. 2014). Table 3 shows the maximum likelihood estimates for parameters of the stochastic frontier model. Almost all inputs have positive correlation with maize profitability except for fertilizer, herbicide, and labor costs that have negative effects on maize output variable.

Table 4 shows the determinants of technical inefficiency in maize production. Inefficiency is the dependent variable in the technical inefficiency model, and as such, variables with a negative (positive) coefficient sign will have a positive (negative) impact on technical efficiency. The analysis found that frequency of extension contact had a negative and significant effect on inefficiency. This implies that farmers with high frequency of extension contact are more technically efficient. Extension officers impart skills to farmers through one-on-one visits, training workshops, advisory services, and promotional events like exchange visits and field days. Farmers can thus learn about new technologies when they are in constant contact with extension, and thus they end up becoming more efficient farmers. This finding is in line with those of Dziwornu and Sarpong (2014), Welch et al. (2016), and Abdulai et al. (2018).

They are also in line with findings from Mango et al. (2015) who found a negative and statistically significant relationship between technical efficiency and extension contact in smallholder farming systems of Zimbabwe following the fast track land reform program. Another researcher, Konja et al. (2019), also found positive impact of extension contact on technical efficiency in certified groundnut seed production in Northern Ghana.

Correspondingly, the coefficient for number of locally available traders was negative and significant. This means that farmers who have access to farm gate traders are technically efficient. Maize farmers in most rural areas are constrained when it comes to capital and hence have difficulties to access distant markets. Therefore, if traders come to buy locally, this acts as an incentive for them to produce that crop knowing there is going to be a guaranteed market with potential to lower 
transaction costs. Furthermore, the coefficient of CSA adoption was negative and significant. This means that farmers using CSA technologies are more efficient.

The stochastic frontier results showed that fertilizer and other costs have negative and significant effect on the inefficiency of maize profitability. The negative signs of the variables indicate that as these variables increase, the profit inefficiency of maize producers decreases. This means a unit increase in costs of the basal dressing fertilizer (DFERT) and top dressing (ANFERT) will lead to $166.68 \%$ and $40.02 \%$ increases in profitability, respectively. Basal and top dressing fertilizer applications are very critical for maize profitability, and the increase in use as proxied by costs will result in increased profitability. Total livestock units (TLU) and farming experience had significant positive coefficients implying that as the farmer's TLU/head size and farming experience increase, the profit inefficiency of the farmers also increases. This contradicts prior expectation and might be explained by the fact that experienced farmers are older and unwilling to invest in any new technologies that come around.

\section{Conclusions and Recommendations}

The most economic adaptation strategy in the face of climate change would be adoption of CSA technologies as evidenced by positive gross margins and higher returns on investment when compared to the conventional way of farming. This is further supported by the positive effect of CSA adoption on technical efficiency. Farmers should however note that not all adaptation strategies are economical; thus, recordkeeping of costs and income for regular computation of costs and benefits is crucial. Farmers can then choose technologies that give higher benefits or those that use less inputs given that most of the farmers are financially constrained. Based on variables that significantly influenced profit efficiency, the study makes three recommendations.

Government should continue putting resources towards supporting mobility of extension staff for continued extension to farmer contact and giving them adequate resource (information materials) so that they continue delivering key information on yield enhancing CSA technologies.

Policies to promote inorganic fertilizer use in order to boost soil fertility remain critical. Government should therefore strengthen the capacity of rural agro dealers to sell fertilizers locally at reasonable prices.

Policies to promote farm gate buying or market centers within wards should also be put in place as they have the potential to increase efficiency if farmers are aware of such a guaranteed market with very low transaction costs.

Declaration This research did not receive any specific grant from funding agencies in the public, commercial, or not-for-profit sectors.

Data Availability The household dataset can be obtained through permission from UKZN. 
Declaration of Competing Interest The authors certify that they have no affiliations with or involvement in any organization or entity with any financial interest (such as honoraria; educational grants; participation in speakers' bureaus; membership, employment, consultancies, stock ownership, or other equity interest; and expert testimony or patent-licensing arrangements) or non-financial interest (such as personal or professional relationships, affiliations, knowledge, or beliefs) in the subject matter or materials discussed in this manuscript.

Acknowledgment The authors wish to appreciate the Ministry of Agriculture officials and Rural District Administrators for granting the permission to do data collection in the sampled districts.

\section{References}

Abate, Tsedeke, Monica F, Tahirou A, Girma TK, Rodney L (2017) Characteristics of Maize Cultivars in Africa : How Modern Are They and How Many Do Smallholder Farmers Grow? Agriculture \& Food Security 6(30):1-17. https://doi.org/10.1186/s40066-017-0108-6

Abdulai S, Nkegbe PK, Donkoh SA, Yildiz F (2018) Assessing the technical efficiency of maize production in northern Ghana: the data envelopment analysis approach. Cogent Food Agric 4 (1):1-14. https://doi.org/10.1080/23311932.2018.1512390

Ali A, Erenstein O (2017) Climate risk management assessing farmer use of climate change adaptation practices and impacts on food security and poverty in Pakistan. Clim Risk Manag 16:183-194. https://doi.org/10.1016/j.crm.2016.12.001

Bell LW, Bellotti B (2014) Whole-farm economic, risk and resource-use trade-offs associated with integrating forages into crop - livestock systems in .... Agric Syst 133:63-72. https://doi.org/ 10.1016/j.agsy.2014.10.008

Dziwornu RK, Sarpong DB (2014) Application of the stochastic profit frontier model to estimate economic efficiency in small-scale broiler production in the Greater Accra region of Ghana. Rev Agric Appl Econ 17(02):10-16. https://doi.org/10.15414/raae.2014.17.02.10-16

FAOSTAT (2020) Food and Agriculture Data. Food and Agriculture Organization of the United Nations. Statistics Division, Rome. http://fenix.fao.org/faostat/internal/en/\#data/QC

GOZ (2018) National Agriculture Policy Framework 2019-2030. Ministry of Lands, Agriculture, Water, Climate and Rural Resettlement, Harare

Greene W (2010) A stochastic frontier model with correction for sample selection. J Prod Anal 34 (1):15-24. https://doi.org/10.1007/s11123-009-0159-1

Kassie GT, Abdulai A, Greene WH, Shiferaw B, Abate T, Tarekegne A, Sutcliffe C (2017) Modeling preference and willingness to pay for drought tolerance (DT) in maize in rural Zimbabwe. World Dev 94:465-477. https://doi.org/10.1016/j.worlddev.2017.02.008

Konja T, Dominic FNM, Oteng-Frimpong R (2019) Profitability and profit efficiency of certified groundnut seed and conventional groundnut production in northern Ghana: a comparative analysis. Cogent Econ Financ 7(1). https://doi.org/10.1080/23322039.2019.1631525

Mango N, Makate C, Hanyani-Mlambo B, Siziba S, Lundy M (2015) A stochastic frontier analysis of technical efficiency in smallholder maize production in Zimbabwe: the post-fast-track land reform outlook. Cogent Econ Financ 3(1):1-14. https://doi.org/10.1080/23322039.2015. 1117189

Michler JD, Baylis K, Arends-Kuenning M, Mazvimavi K (2019) Conservation agriculture and climate resilience. J Environ Econ Manag 93:148-169. https://doi.org/10.1016/j.jeem.2018.11. 008

Mujeyi A (2018) Policy and institutional dimensions in climate-smart agriculture adoption: case of rural communities in Zimbabwe. In: Filho WL (ed) Handbook of climate change resilience. Springer Nature Switzerland AG. https://doi.org/10.1007/978-3-319-71025-9_66-1 
Mujeyi K, Mujeyi A (2018) Fostering climate smartness in smallholder farming systems: business promotional approaches for improved maize varieties in eastern and southern Africa. In: Leal Filho W (ed) Handbook of climate change resilience. Springer International Publishing AG, part of Springer Nature. https://doi.org/10.1007/978-3-319-71025-9_24-1

Karakaplan MU (2017) The Stata Journal. In: The Stata, edited by Joseph H Newton and Nicholas J Cox. Vol. 17. College Station, Texas, USA: The Stata Press

Newton HJ, Cox NJ, Nichols A, Dc W, Gilmore L (2014) The Stata Journal. Stata J 4:778-797

Nsikak-Abasi AE, Okon S (2013) Sources of technical efficiency among smallholder maize farmers in Osun state of Nigeria. Discourse J Agric Food Sci 1(4):48-53. http://docsdrive.com/pdfs/ medwelljournals/rjasci/2010/115-122.pdf

Omhile T, Renato V, David H (2016) Evaluating the productivity gap between commercial and traditional beef production systems in Botswana. AGSY 149:30-39. https://doi.org/10.1016/j. agsy.2016.07.014

Papendiek F, Tartiu VE, Morone P, Venus J (2016) Assessing the economic profitability of fodder legume production for green biorefineries - a cost-benefit analysis to evaluate farmers profitability 112:3643-3656. https://doi.org/10.1016/j.jclepro.2015.07.108

Poole N (2017) Smallholder agriculture market participation. https://doi.org/10.3362/ 9781780449401

Rosenstock TS, Rohrbach D, Nowak A, Girvetz E, Tracking Progress. (2019) The Climate-Smart Agriculture Papers. The Climate-Smart Agriculture Papers. https://doi.org/10.1007/978-3-31992798-5

Rurinda J, Mapfumo P, Van Wijk MT, Mtambanengwe F, Rufino MC (2014) Climate risk management sources of vulnerability to a variable and changing climate among smallholder households in Zimbabwe: a participatory analysis. Clim Risk Manag 3:65-78. https://doi.org/10.1016/j. crm.2014.05.004

Sain G, María A, Corner-dolloff C, Lizarazo M, Nowak A, Martínez-barón D, Andrieu N (2017) Costs and benefits of climate-smart agriculture: the case of the dry corridor in Guatemala. Agric Syst 151:163-173. https://doi.org/10.1016/j.agsy.2016.05.004

Shongwe P, Masuku MB, Manyatsi AM (2014) Cost benefit analysis of climate change adaptation strategies on crop production systems: a case of Mpolonjeni Area Development Programme (ADP) in Swaziland 3(1):37-49. https://doi.org/10.5539/sar.v3n1p37

Siyuan S, Tong L, Liu RH (2018) Corn phytochemicals and their health benefits. Food Sci Human Wellness 7(3):185-195. https://doi.org/10.1016/j.fshw.2018.09.003

Steward PR, Dougill AJ, Thierfelder C, Pittelkow CM, Stringer LC, Kudzala M, Shackelford GE (2018) The adaptive capacity of maize-based conservation agriculture systems to climate stress in tropical and subtropical environments: a meta-regression of yields. Agric Ecosyst Environ 251(2017):194-202. https://doi.org/10.1016/j.agee.2017.09.019.

Thierfelder C, Chivenge P, Mupangwa W, Rosenstock TS, Lamanna C, Eyre JX (2017) How climate-smart is conservation agriculture (CA)? - its potential to deliver on adaptation, mitigation and productivity on smallholder farms in Southern Africa. https://doi.org/10.1007/s12571017-0665-3

UNCCS (2019) Climate action and support trends. United Nations Climate Change Secretariat, Bonn

Villano R, Fleming E (2006) Technical inefficiency and production risk in Rice farming: evidence from Central Luzon Philippines. Asian Econ J 20(1):29-46. https://doi.org/10.1111/j.14678381.2006.00223.x

Waddington SR, Karigwindi J, Chifamba J (2007) The sustainability of a groundnut plus maize rotation over 12 years on smallholder farms in the sub-humid zone of Zimbabwe. African Journal of Agricultural Research. 2(8):342-348

Wang H-J (2008) Stochastic frontier models. In: The new Palgrave dictionary of economics, pp 925-928. https://doi.org/10.1057/9780230226203.1623

Welch EW, Villanueva AB, Jha Y, Ogwal-omara R, Welch E, Wedajoo S, Halewood M (2016) Adoption of climate smart technologies in East Africa findings from two surveys and participatory exercises with farmers and local and experts. https://doi.org/10.13140/RG.2.2.24562. 09927 
Open Access This chapter is licensed under the terms of the Creative Commons Attribution 4.0 International License (http://creativecommons.org/licenses/by/4.0/), which permits use, sharing, adaptation, distribution and reproduction in any medium or format, as long as you give appropriate credit to the original author(s) and the source, provide a link to the Creative Commons license and indicate if changes were made.

The images or other third party material in this chapter are included in the chapter's Creative Commons license, unless indicated otherwise in a credit line to the material. If material is not included in the chapter's Creative Commons license and your intended use is not permitted by statutory regulation or exceeds the permitted use, you will need to obtain permission directly from the copyright holder.

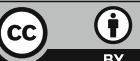

